УДК 636.09:636.4

doi: 10.36359/scivp.2019-20-2.19

\title{
ЕФЕКТИВНІСТЬ ПРЕПАРАТУ НА ОСНОВІ КОЛІСТИНУ ПРИ ЛІКУВАННІ КИШКОВИХ ІНФЕКЦИЙ ПОРОСЯТ
}

\author{
Н. В. Шкодяк, канд. вет. наук, \\ Н. Е. Лісова, канд. с.-г. наук, \\ О. М. П'ятничко, канд. с.-г. наук, \\ О. Й. Сободош, канд. вет. наук, \\ О. А. Максимович, молодший науковий співробітник \\ О. 3. Балян, старший науковий співробітник
}

Державний науково-дослідний контрольний інститут ветеринарних препаратів та кормових добавок

вул. Донецька, 11, м. Львів, 79019, Україна

У статті викладено результати клінічного дослідження вітчизняного ветеринарного препарату на основі колістину (Колістовету) при лікуванні поросят із гострими захворюваннями шлунково-кишкового тракту бактеріальної етіологіі. Встановлено терапевтичну ефективність і безпечність досліджуваного препарату при лікуванні хворих поросят 2-2,5-місячного віку.

Вивчали морфологічні та біохімічні показники крові дослідних тварин, за умов застосування Колістовету. Виявлено тенденцію до збільшення вмісту гемоглобіну, вірогідне зменшення відносної кількості паличкоядерних нейтрофілів і збільшення відсоткового вмісту лімфочитів, порівняно з показниками до лікування.

На підставі імунологічних показників та показників активності ферментів АлАТ, АсАТ, ЛФ у сироватиі крові поросят встановлено позитивний вплив препарату Колістовет на поступове відновлення функиіонального стану гепатобіліарної системи, а також активацію клітинної ланки неспецифічної резистентності організму тварин.

Ключові слова: ПОРОСЯТА, ГОСТРЕ ЗАХВОРЮВАННЯ ШЛУНКОВОКИШКОВОГО ТРАКТУ, КОЛІСТОВЕТ, АНТИБІОТИКОТЕРАПІЯ, МОРФОЛОГІЧНІ ТА БІОХІМІЧНІ ПОКАЗНИКИ КРОВІ, ТЕРАПЕВТИЧНА ЕФЕКТИВНІСТЬ.

Широке використання антибіотиків у сільському господарстві призвело до стійкості збудників до багатьох антимікробних засобів у тваринництві та птахівництві [1]. Відтак, резистентність мікроорганізмів до антимікробних препаратів стала однією 3 найбільших проблем у галузі здоров'я людей та тварин. Застосування профілактичних заходів, імуномодуляторів не зможе цілковито вирішити цієї проблеми, але при виникненні захворювань бактеріальної етіології перш за все необхідне застосування хіміотерапевтичних засобів, які діють на збудника, ліквідують хворобу і дозволяють запобігти втратам поголів'я та економічним збиткам [1,2].

Поява множинно-резистентних збудників змушує переглядати ставлення до відомих і давно використовуваних препаратів, зокрема до поліміксинів - групи поліпептидних антибіотиків, продукованих Bacillus polymyхa. Поліміксини виділені ще в 40-х роках минулого століття, а лікарські засоби на основі поліміксину застосовували з 60 -х років, проте їхнє застосування швидко скоротилося через кількість побічних ефектів (нефро- та нейротоксичність, гематологічні реакції, порушення метаболічного балансу) та доступність антибіотиків з меншою побічною дією. Частково завдяки цьому обмеженню для застосування натрій колістиметату зберіг активність проти ряду бактерій, які стали резистентними до 
антибіотиків, що зазвичай застосовуються. Останніми роками це призвело до повернення застосування поліміксинів у випадках відсутності інших варіантів лікування. Натрій колістиметат, зокрема, застосовують при лікуванні серйозних інфекцій, що викликані грамнегативними аеробними патогенними мікроорганізмами у пацієнтів 3 обмеженим вибором терапії $[2,3]$.

У ветеринарній медицині використовується поліміксин колістин (у вигляді сульфату), продукований Bac. polymyxa var. colistinus. Колістину сульфат переважно активний щодо синьогнійної палички, кишкових бактерій (кишкова паличка, шигели, сальмонели), а також капсульних бактерій, пастерели. Рівень резистентності до колістину незначний і розвивається повільно [3, 4]. У кишечнику накопичуються високі концентрації препарату, оскільки 3 шлунково-кишкового тракту (ШКТ) він всмоктується погано, а тому призначають колістин при кишкових інфекціях у свиней та свійської птиці [4].

Мета нашого дослідження - вивчити лікувальну ефективність та безпечність препарату Колістовет (порошок для перорального застосування) виробництва ТОВ «Укрветпромпостач» (Україна) при лікуванні гострих інфекцій ШКТ бактеріальної етіології у свиней.

Матеріали і методи. Для досліду було підібрано поросят віком, 2-2,5 місяці в умовах фермерського господарства ТзОВ «ГаличХутро» (с. Велике Сокальського району Львівської області). Захворювання тварин характеризувалося ураженням ШКТ і респіраторних органів. Виникненню захворювання сприяв ряд зовнішніх чинників, а саме: рання відлучка від свиноматок, перегрупування, незадовільний мікроклімат в приміщенні, переохолодження, неповноцінна годівля тощо. Діагноз ставили ветеринарні фахівці господарства та ДНДКІ ветпрепаратів та кормових добавок на основі комплексного аналізу епізоотологічних даних, клінічних ознак, патолого-анатомічних змін і результатів бактеріологічного дослідження. Виявлено, що збудником захворювання була грамнегативна бактерія родини ентеробактерій Klebsiella pneumoniae, чутлива до колістину.

Для дослідження ефективності препарату Колістовет при лікуванні клебсіельозу молодняку свиней в умовах свиноферми були відокремлені хворі поросята (15 голів). Поросятам застосовували препарат Колістовет перорально з кормом у дозі 200 г препарату на 1 т корму, впродовж 7 діб. Протягом лікування та 14 діб після проведеної антибіотикотерапії вели постійне спостереження за клінічним станом тварин, фіксуючи будь-які відхилення від фізіологічної норми та поведінки, появу побічних реакцій та виникнення рецидивів захворювання.

Морфо-функціональний стан організму тварин до та після лікування контролювали за морфологічними та біохімічними показниками крові. Лабораторні дослідження крові поросят, відібраної до та на 14 добу після застосування препарату, проведено в лабораторії клінікобіологічних досліджень ДНДКІ ветпрепаратів та кормових добавок. Для оцінки стану організму та характеристики змін було підібрано ряд лабораторних тестів, що відповідали клінічним вимогам [5-8]. Для морфологічних досліджень використовували стабілізовану ЕДТА кров, а для біохімічних досліджень - сироватку крові. В крові визначали: вміст гемоглобіну, кількість еритроцитів, гематокрит, кількість лейкоцитів - за допомогою гематологічного аналізатора Mythic-18; лейкоформулу - на основі мікроскопії мазків крові із диференціальним підрахунком різних форм лейкоцитів - за загальноприйнятими методиками [6-7].

Фагоцитарну активність лейкоцитів визначали за Чумаченком В. В. (1990). Для оцінки функціональної активності нейтрофільних гранулоцитів використали показники, які визначали традиційними методами: фагоцитарну активність (ФА), фагоцитарний індекс (IФ, інтенсивність фагоцитозу). Здатність нейтрофільних гранулоцитів до фагоцитозу встановлювали за такими показниками: індекс Гамбургера (процент нейтрофілів, які беруть участь у фагоцитозі), індекс Райта (середнє число мікробів, захоплених одним лейкоцитом). Оцінку фагоцитозу in vitro проводили через 30 хв. після початку інкубації з культурою 
мікроорганізмів E. coli. Інтенсивність фагоцитозу оцінювали за показником фагоцитарного індекса. Загальний вміст білка в сироватці крові визначали за допомогою рефрактометра IРФ22. Активність ферментів (АлАТ, АсАТ, ЛФ), вміст креатиніну визначали за допомогою напівавтоматичного біохімічного аналізатора (HumaLyzer 3000).

Отримані результати обробляли статистично, оцінюючи вірогідність різниці показників ( $<0,05$,$) за критерієм Стьюдента [10].$

Результати й обговорення. Клінічний огляд тварин протягом досліду засвідчив, що симптоми захворювання у поросят почали зникати на 3-4 добу лікування. У більшості тварин припинилася діарея, поступово припинився кашель, дихання поступово ставало грудочеревним, рівним та ритмічним. У поросят покращувався загальний стан, відновлювався апетит, активнішою ставала поведінка. Однак у двох тварин хвороба перейшла в хронічну форму (тварини час від часу поносили, кашель не припинився, поросята значно відставали в рості та розвитку від своїх ровесників). У інших тварин клінічний огляд показав відсутність будь-яких симптомів захворювання. Таким чином, терапевтична ефективність досліджуваного препарату Колістовет при лікуванні клебсіельозу молодняку свиней становила 86,7 \%. Застосування досліджуваного препарату не викликало ускладнень та побічних ефектів, а також не було зафіксовано рецидивів захворювання у поросят, що клінічно одужали. Під час проведеного лікування та протягом 14 діб після антибіотикотерапії не спостерігалося будьяких відхилень у поведінці та не відзначалося побічних явищ у тварин.

За результатами гематологічних досліджень у хворих поросят до лікування встановлено концентрацію гемоглобіну на рівні нижньої границі норми, а кількість лейкоцитів більшу від нормальних параметрів для даної вікової групи (табл. 1). При цьому відсотковий вміст лімфоцитів був менший від норми, а відносна кількість паличкоядерних нейтрофілів більша від нормальних величин для даного виду тварин. Отримані дані вказували на недостатній імунний потенціал організму та наявність запальних процесів в організмі досліджуваних поросят, викликаних бактеріальною інфекцією органів травлення.

Таблиия 1

Гематологічні показники поросят при клінічному дослідженні препарату Колістовет $(\mathrm{M} \pm \mathbf{m}, \mathbf{n}=10)$

\begin{tabular}{|c|c|c|c|}
\hline Показники & До лікування & Після лікування & Фізіологічні межі \\
\hline Гемоглобін, г/л & $93,4 \pm 2,7$ & $101,6 \pm 4,7$ & $90-120$ \\
\hline Еритроцити, Т/л & $5,9 \pm 0,3$ & $6,9 \pm 0,4$ & $5-8$ \\
\hline Гематокрит, \% & $37,2 \pm 0,9$ & $38,7 \pm 3,1$ & $33-45$ \\
\hline Лейкоцити, г/л & $17,2 \pm 2,1$ & $14,6 \pm 1,8$ & $8-16$ \\
\hline Еозинофіли,\% & $2,4 \pm 0,8$ & $2,4 \pm 0,8$ & $1-3$ \\
\hline Нейтрофіли паличкоядерні \% & $10,4 \pm 0,8$ & $7,2 \pm 0,6^{*}$ & $5-8$ \\
\hline Нейтрофіли сегментоядерні, \% & $46,0 \pm 2,0$ & $41,6 \pm 2,7$ & $20-48$ \\
\hline Моноцити, \% & $3,6 \pm 0,8$ & $5,6 \pm 0,8$ & $2-5$ \\
\hline Лімфоцити, \% & $37,6 \pm 1,3$ & $41,2 \pm 1,9$ & $40-52$ \\
\hline
\end{tabular}

При аналізі даних біохімічних досліджень, проведених до антибіотикотерапії, відзначено, що вміст загального білка і креатиніну у сироватці крові поросят був на нижній межі норми для даної вікової групи (табл. 2). Окрім цього, в сироватці крові тварин до лікування виявлено суттєво вищу активність амінотрансфераз і ЛФ, порівняно з величинами норми. Це свідчило про функціональні порушення в гепатобіліарній системі поросят із гострими захворюваннями ШКТ бактеріальної етіології [9].

Аналіз імунологічних показників сироватки крові хворих поросят показав, що до початку лікування фагоцитарна активність була нижче норми, а показник ФІ - вище верхньої границі норми для тварин даного віку (табл. 2).

На 14 добу після проведення курсу антибіотикотерапії встановлено тенденцію до збільшення вмісту гемоглобіну у крові досліджуваних поросят, поступову стабілізацію показників лейкограми - збільшення відсоткового вмісту лімфоцитів і вірогідне зменшення 
відносної кількості паличкоядерних нейтрофілів на 30,8 \%, порівняно з періодом до лікування. Отримані дані вказують на пригнічення запальних процесів та відновлення фізіологічного гомеостазу в організмі тварин.

Таблиия 2

Біохімічні та імунологічні показники крові поросят при клінічному дослідженні препарату Колістовет $(\mathrm{M} \pm \mathbf{m}, \mathbf{n}=\mathbf{1 0})$

\begin{tabular}{|c|c|c|c|}
\hline Показники & До лікування & Після лікування & Фізіологічні межі \\
\hline Загальний білок, г/л & $49,5 \pm 3,7$ & $57,4 \pm 4,0$ & $50-65$ \\
\hline ЛФ, Од/л & $951,7 \pm 63,3$ & $711,9 \pm 76,0^{*}$ & $100-500$ \\
\hline АлАТ, Од/л & $95,4 \pm 7,8$ & $62,8 \pm 5,8^{*}$ & $10-50$ \\
\hline АсАТ, Од/л & $90,4 \pm 3,0$ & $71,6 \pm 5,2^{*}$ & $88-200$ \\
\hline Креатинін, мкмоль/л & $76,5 \pm 2,7$ & $83,0 \pm 4,2$ & $16-60$ \\
\hline ФА, \% & $14,8 \pm 1,8$ & $17,6 \pm 1,6$ & $3-7$ \\
\hline ФІ, м.т./нейтр. & $8,8 \pm 1,3$ & $11,4 \pm 1,8$ & \\
\hline
\end{tabular}

При аналізі біохімічних показників у сироватці крові тварин встановлено збільшення концентрації загального білка на 15,9 \% та вірогідне зниження активності АлАТ на 34,2 \% $(\mathrm{p}<0,05)$, АсАТ на 20,8 \%, ЛФ на 25,2 \% (p<0,05), порівняно з періодом до лікування. При цьому, активність усіх вказаних ензимів у крові поросят на 14 добу досліду залишалася вищою від нормальних величин (табл. 2).

За результатами імунологічних досліджень крові поросят після застосування колістовету виявлено, що ФА зросла на 18,9 \%, а показник інтенсивності фагоцитозу (ФІ) зріс на 29,5 \%. Отже, динаміка показників клітинної ланки неспецифічної резистентності свідчила про посилення протимікробного захисту поросят.

Отже, результати гематологічних i біохімічних досліджень при клінічних випробуваннях препарату Колістовет підтвердили його терапевтичну ефективність та безпечність при лікуванні гострих захворювань ЖКТ бактеріальної етіології у молодняку свиней.

\title{
В И С Н О В К И
}

1. Виробниче випробування препарату Колістовет, порошок для перорального застосування, виробництва ТЗОВ «Укрветпромпостач» (Україна), показало його ефективність при терапії бактеріальних інфекцій травного тракту у молодняку свиней, викликаних чутливими до діючої речовини препарату мікроорганізмами.

2. За результатами проведених лабораторних досліджень, після застосування препарату для лікування клебсіельозу поросят, встановлено поступове відновлення фізіологічного стану тварин, що загалом свідчило про пригнічення запальних процесів та покращення їх клінічного стану і вказувало на ефективність проведеного лікування.

3. Отримані морфологічні, імунологічні та окремі біохімічні показники крові поросят свідчать про відсутність ознак імунотоксичного, гепатотоксичного та нефротоксичного впливу досліджуваного препарату.

Перспективи досліджень. Планується дослідження ефективності препаратів на основі колістину у при лікуванні респіраторних гострих бактеріальних захворювань у поросят.

\section{EFFICIENCY OF THE PREPARATION ON THE BASIS OF COLISTINE FOR TREATMENT OF GASTROINTESTINAL INFECTIONS OF PIGLETS}

\author{
N. Shkodyak, N. Lisova, O. Pyatnychko, O. Sobodosh, O. Maksymovych, O. Balyan
}

State Scientific-Research Control Institute of Veterinary Medicinal Product and Feed Additives 11, Donetska str., Lviv, 79019, Ukraine 


\title{
S U M M A R Y
}

The article presents the results of clinical trials of veterinary preparation on the basis of colistine (Colistovet) under the treatment of piglet's acute gastro-intestinal diseases of bacterial etiology. The therapeutic efficiency and safety of preparation under the treatment of 2-2,5 months of age sick piglets has been proved.

Clinical trials were conducted on the base of the farm TZOV "Halych Khutro" (Velyke village, Sokalsky district, Lviv region). For the experiment piglets aged 2-2,5-months were selected. Disease of animals was characterized by acute gastrointestinal and respiratory diseases. The emergence of the disease contributed to a number of external factors, namely: early isolation from sows, regrouping, poor indoor microclimate, hypothermia, malnutrition, and the others. The diagnosis was put up by veterinary specialists of farm and DNDKI of veterinary preparations on the basis of complex analysis of epizootological data, clinical signs, pathologic-anatomical changes and results of bacteriological researches. It was found that the pathogens of the disease were gramnegative bacteria of the family of enterobacteria Klebsiella pneumoniae, sensitive to colistinum. Preparation Colistovet was administered to piglets orally with food in a dose of $200 \mathrm{~g}$ per 1 ton of feed daily for seven days. Laboratory blood tests for evaluation of physiological state of the piglet's organism and biochemical homeostasis were carried out before the use of drugs and at 14 days after the use of the drug. Morpho-functional state of the piglet's organism before and after treatment established by morphological and biochemical indices of blood that determined in accordance with generally accepted methods. The morphological (number of red blood cells, the number of white blood cells, hematocrit value, hemoglobin concentration, leukocytogram by conventional methods and biochemical (total protein concentration, creatinine, activity of ALT, AST, AP) piglet's blood parameters were studied on biochemical analyzer Humalyzer 3000 using sets of reagents and standards firm Human.

The influence of preparation Colistovet on haematological and biochemical parameters of piglet's blood was studied. The tendency to increasing of blood haemoglobin concentration, reliable reduction of neutrophils stab quantity and increasing of lymphocytes relative quantity were established after the drug's application. On the basis of immunological parameters and indicators of the activity of the enzymes AlAT, AsAT, alkaline phosphatase in the serum of piglets, the positive effect of drug on the gradual restoration of the functional state of the hepatobiliary system, as well as the activation of the cellular link of nonspecific resistance in animal's organism, was established.

The preparation Colistovet is effective during the treatment of piglets with acute gastrointestinal diseases of bacterial etiology. This is confirmed by the improvement of their clinical condition and normalization of majority of piglet's blood indices.

Keywords: PIGLETS, ACUTE GASTRO-INTESTINAL DISEASES, COLISTOVET, ANTIBIOTIC THERAPY, MORPHOLOGICAL AND BIOCHEMICAL BLOOD INDICES, THERAPEUTIC EFFICIENCY.

\section{ЭФФЕКТИВНОСТЬ ПРЕПАРАТА НА ОСНОВЕ КОЛИСТИНА ПРИ ЛЕЧЕНИИ КИШЕЧНЫХ ИНФЕКЦИЙ ПОРОСЯТ}

\author{
Н. В. Шкодяк, Н. Э. Лисовая, О. М. Пятничко, О. И. Сободош, О. А. Максимович, О. З. Балян
}

Государственный научно-исследовательский контрольный институт ветеринарних препаратов и кормовых добавок

ул. Донецкая, 11, г. Львов, 79019, Украина

\section{А Н Н О Т А ЦИ Я}

В статье изложены результаты клинического исследования отечественного ветеринарного препарата на основе колистина (Колистовета) при лечении поросят с острыми 
заболеваниями желудочно-кишечного тракта бактериальной этиологии. Установлено терапевтическую эффективность и безопасность исследуемого препарата при лечении животных 2-2,5-месячного возраста.

Изучали морфологические и биохимические показатели крови больных поросят при применении препарата Колистовет. Выявлено тенденцию к увеличению содержания гемоглобина, достоверное уменьшение относительного количества палочкоядерных нейтрофилов и увеличение количества лимфоцитов в крови животных, сравнительно с показателями до лечения. На основании иммунологических показателей и показателей активности ферментов АлАТ, АсАТ, ЩФ в сыворотке крови поросят установлено положительное влияние препарата Колистовет на постепенное восстановление функционального состояния гепатобилиарной системы, а также активацию клеточного звена неспецифической резистентности организма животных.

Ключевые слова: ПОРОСЯТА, ОСТРЫЕ ЗАБОЛЕВАНИЯ ЖЕЛУДОЧНОКИШЕЧНОГО ТРАКТА, КОЛИСТОВЕТ, АНТИБИОТИКОТЕРАПИЯ, МОРФОЛОГИЧЕСКИЕ И БИОХИМИЧЕСКИЕ ПОКАЗАТЕЛИ КРОВИ, ТЕРАПЕВТИЧЕСКАЯ ЭФФЕКТИВНОСТЬ.

\section{Л I T E P A T У P A}

1. Гунчак В. М. Особливості антибіотикотерапії у сучасній ветеринарній медицині/ В. М. Гунчак, Т. І. Стецько // Науковий вісник ЛНУВМБ ім. Гжицького. - 2012. - Т. 14, № 2 (1). - C. 73-84.

2. Виолин Б. В. Химиотерапия при бактериальных и паразитарных болезнях / Б. В. Виолин., В. Е. Абрамов, В. Ф. Ковалев // Ветеринария. - 2001. - № 1. - С. 17-18.

3. Prescott J. F. Antimicrobial therapy in veterinary medicine / J. F. Prescott, J. D. Baggot. — 2nd ed. Ames, IA: Iowa State University Press. - 1993. - P. 90-95.

4. Стецько T. I. Порівняльна ефективність нового вітчизняного антибактеріального препарату на основі колістину за лікування колібактеріозу телят / T. І. Стецько, В. Н. Падовський, О. М. Дубін // Науковий вісник ветеринарної медицини - Біла Церква, 2018. - № 1. - С. 138-144.

5. Клінічні дослідження ветеринарних препаратів та кормових добавок /І. Я. Коцюмбас, І. Ю. Бісюк, В. М. Горжеєв [та ін.]; за ред. І. Я. Коцюмбаса. - Львів, ТОВ Видавничий дім «САМ», 2013. - 252 с.

6. Комплексна оцінка впливу ветеринарних препаратів на морфофункціональний стан імунної системи: Методичні рекомендації / Коцюмбас І. Я., Коцюмбас Г. І., Голубій Є. М. та ін. - Львів, 2009. - 63 с.

7. Лабораторні методи дослідження у біології, тваринництві та ветеринарній медицині: довідник / В. В. Влізло, Р. С. Федорук, І. Б. Ратич та ін.; за ред. В. В. Влізла. - Львів: Сполом, 2012. $-764 \mathrm{c}$.

8. Казмірчук B. $\epsilon$. Інтерпретація лейкограми та імунограми згідно з сучасними позиціями/ В. С. Казмірчук // Внутренняя медицина. - 2007. - Т.4 (4) - С. 1-17.

9. Катеренчук I. П. Клінічне тлумачення і діагностичне значення лабораторних показників у клініці внутрішньої медицини: Навчальний посібник/I. П. Катеренчук // Полтава, 2015. - $270 \mathrm{c}$.

10. Мазур T. Константні методи математичної обробки кількісних показників /Т. Мазур // Ветеринарна медицина України. - 1998. - № 11. - С. 35-37. 


\section{References}

1. Gunchak V. M. Osoblyvosti antybiotykoterapii' u suchasnij veterynarnij medycyni/ V. M. Gunchak, T. I. Stec'ko // Naukovyj visnyk L'vivs'kogo nacional'nogo universytetu veterynarnoi' medycyny ta biotehnologij im. G'zhyc'kogo. - 2012. - T. 14, № 2 (1). - S. 73-84. (in Ukrainian)

2. Vyolyn B. V. Hymyoterapyja pry bakteryal'nyh y parazytarnyh boleznjah / B. V. Vyolyn, V. E. Abramov, V. F. Kovalev // Veterynaryja. - 2001. - № 1. - S. 17-18. (in Russian)

3. Prescott J. F. Antimicrobial therapy in veterinary medicine / J. F. Prescott, J. D. Baggot. 2nd ed. Ames, IA: Iowa State University Press. - 1993. - P. 90-95.

4. Stec'ko T. I. Porivnjal'na efektyvnist' novogo vitchyznjanogo antybakterial'nogo preparatu na osnovi kolistynu za likuvannja kolibakteriozu teljat / T. I. Stec'ko, V. N. Padovs'kyj, O. M. Dubin // Naukovyj visnyk veterynarnoi' medycyny - Bila Cerkva, 2018. - № 1. - S. 138-144. (in Ukrainian)

5. Klinichni doslidzhennja veterynarnyh preparativ ta kormovyh dobavok /I. Ja. Kocjumbas, I. Ju. Bisjuk, V. M. Gorzhejev, O. G. Malyk [ta in.]; za red. I. Ja. Kocjumbasa. - L'viv, TOV Vydavnychyj dim «SAM», 2013. — 252 s. (in Ukrainian)

6. Kompleksna ocinka vplyvu veterynarnyh preparativ na morfofunkcional'nyj stan imunnoi' systemy: Metodychni rekomendacii' /Kocjumbas I. Ja., Kocjumbas G. I., Golubij Je. M. ta in. L'viv, 2009. - 63 s. (in Ukrainian)

7. Laboratorni metody doslidzhennja u biologii', tvarynnyctvi ta veterynarnij medycyni: dovidnyk / V. V. Vlizlo, R. S. Fedoruk, I. B. Ratych ta in.; za red. V. V. Vlizla. - L'viv: Spolom, 2012. - 764 s. (in Ukrainian)

8. Kazmirchuk V. Je. Interpretacija lejkogramy ta imunogramy zgidno z suchasnymy pozycijamy/ V. Je. Kazmirchuk // Vnutrennjaja medycyna. - 2007. -T. 4 (4) - S. 1-17. (in Ukrainian)

9. Katerenchuk I. P. Klinichne tlumachennja i diagnostychne znachennja laboratornyh pokaznykiv u klinici vnutrishn'oi' medycyny: Navchal'nyj posibnyk/I. P. Katerenchuk// Poltava, 2015. - 270 s. (in Ukrainian)

10. Mazur T. Konstantni metody matematychnoi' obrobky kil'kisnyh pokaznykiv/T. Mazur // Veterynarna medycyna Ukrai'ny. - 1998. — № 11. - S. 35-37. (in Ukrainian)

Рецензент - Б. В. Гутий, д. вет. н., професор, ЛНУВМБ імені С. З. Гжицького. 